\title{
PENAMBAHAN RIMPANG KUNYIT (CURCUMA DOMESTICA VAL.), TEMULAWAK (CURCUMA XANTHORRHIZA ROXB.), DAN TEMU PUTIH (CURCUMA ZEDOARIA ROSC.) DALAM RANSUM KOMERSIL TERHADAP KUALITAS TELUR BURUNG PUYUH (Coturnix-coturnix japonica) \\ Claudia Rondonuwu*, J. L. P. Saerang**, F. J. Nangoy**, S. Laatung**
}

Fakultas Peternakan Universitas Sam Ratulangi Manado, 95115

\begin{abstract}
ABSTRAK
Penelitian ini bertujuan untuk mengetahui kualitas telur burung puyuh setelah ditambahkan $2 \%$ rimpang kunyit (Curcuma domestica Val.), temulawak (Curcuma xanthorrhiza Roxb.), dan temu putih (Curcuma zedoaria Rosc.) dalam ransum komersil. Ternak yang digunakan yaitu burung puyuh dari jenis Coturnix-coturnix japonica betina umur 6 minggu sebanyak 120 ekor. Penelitian menggunakan metode Rancangan Acak Lengkap (RAL) dengan 4 perlakuan dan 5 ulangan, dan setiap ulangan terdiri dari 6 ekor burung puyuh. Perlakuan yang diberikan yaitu : R0 = ransum kontrol; $\mathrm{R} 1=$ ransum dengan $2 \%$ kunyit (Curcuma domestica Val.); R2 = ransum dengan 2\% temulawak (Curcuma xanthorrhiza Roxb.); dan R3 = ransum dengan 2\% temu putih (Curcuma zedoaria Rosc.). Hasil penelitian menunjukkan bahwa penambahan $2 \%$ rimpang kunyit, temulawak, temu putih memberikan pengaruh tidak berbeda nyata terhadap berat telur, warna kuning telur dan tebal kerabang. Berdasarkan hasil penelitian dapat disimpulkan bahwa penambahan $2 \%$ rimpang kunyit (Curcuma domestica Val.), temulawak (Curcuma xanthorrhiza Roxb.), dan temu putih (Curcuma zedoaria Rosc.) belum dapat meningkatkan berat telur, warna kuning telur, dan tebal kerabang telurbila di tambahkan pada ransum komersil.
\end{abstract}

*Alumni Fakultas Peternakan Unsrat

**Jurusan Produksi Ternak
Kata Kunci : Ransum, Kunyit, Temulawak, Temu Putih, Telur Puyuh.

\begin{abstract}
ADDITION TURMERIC GINGER, RHIZOME AND WHITE RHIZOME OF COMMERCIAL RATION TO EGGS' QUALITY OF QUAILS.This study aims to determine the quality of quail eggs after added 2\% turmeric (Curcuma domestica Val.), ginger (Curcuma xanthorrhiza Roxb.), and ginger and white (Curcuma zedoaria Rosc.) in the commercial ration. Animals used are of the type Coturnixcoturnix japonica quail females aged 6 weeks a total of 120 birds. Research using completely randomized design (CRD) with 4 treatments and 5 replications, and each replication consisted of 6 tail quail. Treatment is given as follows: $\mathrm{R} 0=$ control diet; $\mathrm{R} 1=$ ration with $2 \%$ turmeric (Curcuma domestica Val.), $\mathrm{R} 2=2 \%$ ration with ginger (Curcuma xanthorrhiza Roxb.), $\mathrm{R} 3=2 \%$ ration with ginger and white (Curcuma zedoaria Rosc.). results of the study showed that the addition of $2 \%$ turmeric (Curcuma domestica Val.), ginger (Curcuma xanthorrhiza Roxb.), ginger and white (Curcuma zedoaria Rosc.) and not significantly different effect on egg weight, yolk color and egg shell thickness. And based on the results of this study concluded that the addition of $2 \%$ turmeric, ginger, ginger and white and can not increase egg weight, yolk
\end{abstract}


color and egg shell thickness when added to a commercial ration.

Keyword : Ration, Turmeric, Ginger, Ginger and White, Quail Eggs.

\section{PENDAHULUAN}

Pemberian pakan tambahan yang baik pada burung puyuh tentunya akan berpengaruh pada kualitas telur. Salah satu pakan tambahan yang baik diberikan kepada burung puyuh adalah pakan yang berasal dari bahan herbal. Kunyit (Curcuma domestica Val.), temulawak (Curcuma xanthorrhiza Roxb.), dan temu putih (Curcuma zedoaria Rosc.) adalah beberapa contoh bahan herbal yang dapat digunakan sebagai pakan tambahan alternatif bagi ternak unggas.

Kunyit (C. domestica Val.) dan temulawak (C. xanthorrhiza Roxb.) merupakan tanaman herbal yang termasuk dalam antibiotik alami dan tidak mengakibatkan residu atau bahaya apabila dikonsumsi oleh ternak maupun manusia. Kandungan zat aktif yang terkandung dalam kunyit ( $C$. domestica Val.) dan temulawak ( $C$. xanthorrhiza Roxb.) adalah kurkuminoid dan minyak atsiri. Kurkuminoid berfungsi meningkatkan nafsu makan yang pada akhirnya akan meningkatkan bobot hidup unggas. Sedangkan minyak atsiri berfungsi sebagai kalagoga dalam hal ini dapat meningkatkan sekresi cairan empedu. (Atmajaya et al, 2014). Anggraini (2012) menambahkan bahwa kandungan senyawa senyawa aktif temulawak $(C$. xanthorrhiza Roxb.) dan kunyit ( $C$. domestica Val.) berpotensi untuk dijadikan feed additive herbal untuk ternak ayam broiler sebagai pengganti antibiotik sintetik. Rimpang temu putih (C. zedoaria Rosc.) mengandung sinol, kamfena, sesquiterpealkohol, kurkumenon, kurkumenolida, germakron, furanodienon, kurkumanol, isokurkumenol, kurzerenon, zederon, dehidrokudion, kurdion, prokurkumenol, isofuran dienon, furanodiena, kurkumin (Heyne, 1987).Penelitian-penelitian mengenai penggunaan herbal kunyit $(C$. domestica Val.), temulawak ( $C$. xanthorrhiza Roxb.), dan temu putih (C. zedoaria Rosc.) secara tunggal sebagai pakan tambahan, telah banyak dilakukan baik pada unggas petelur maupun pedaging. Salah 
satunya adalah hasil penelitian yang dilaporkan oleh Zainuddin (2010) menyatakan bahwa ternak ayam ras broiler, petelur maupun unggas lokal (ayam dan itik) yang diberi ramuan tanaman obat sebagai "feed additive" menunjukkan peningkatan terhadap efisiensi pakan dan kesehatan ternak. Belum ada informasi mengenai penggunaan ketiga herbal tersebut sebagai pakan tambahan untuk burung puyuh. Berdasarkan latar belakang yang sudah diuraikan diatas, maka telah dilakukan penelitian untuk melihat pengaruh penambahan kunyit $(C$. domestica Val.), temulawak (C. xanthorrhiza Roxb.), dan temu putih (C. zedoaria Rosc.) dalam ransum komersil terhadap kualitas telur burung puyuh (Coturnix-coturnix japonica).

\section{MATERI DAN METODE PENELITIAN}

Sebanyak 120 burung puyuh jenis Coturnix-coturnix japonica digunakan dalam penelitian ini, yang secara acak dibagi menjadi 4 perlakuan ransum dengan 5 ulangan dan setiap ulangan terdiri dari 6 ekor burung puyuh. Kandang yang digunakan dalam penelitian ini adalah kandang battery koloni sebanyak 20 petak yang terdiri dari 4 tingkat yang disekat. Setiap petak mempunyai panjang $50 \mathrm{~cm}$, lebar 40 $\mathrm{cm}$. Masing-masing kandang dilengkapi tempat pakan, tempat minum, dan tempat telur.

Perlakuan menggunakan ransum komersil PT. Charoen Pokphan BP-104 dengan penambahan rimpang kunyit $2 \%$, temulawak $2 \%$, dan temu putih $2 \%$. Perlakuan yang diberikan adalah sebagai berikut :

$\mathrm{R} 0=$ Ransum komersial (BP 104)

R1 = Ransum komersial (BP 104) + $2 \%$ kunyit

$\mathrm{R} 2$ = Ransum komersial (BP 104) + $2 \%$ temulawak

R3 = Ransum komersial (BP 104) + $2 \%$ temu putih

\section{Variabel Penelitian}

- Berat telur : Berat telur ditimbang menggunakan timbangan digital satuan gram (g)

- Warna kuning telur : Pengukuran warna kuning telur ini menggunakan Yolk Colour Fan. Skor warna kuning telur 
memiliki standar warna 1-15, dengan menggunakkan ANOVA semakin tinggi skor warna sesuai dengan rancangan yang kuning telur maka semakin baik kualitas telur tersebut digunakan yaitu Rancangan Acak (Muharlien, 2010).

- Tebal kerabang : Pengukuran HASIL DAN PEMBAHASAN tebal kerabang telur dilakukan pada bagian ujung tumpul, tengah (ekuator), dan ujung lancip telur kemudian dibuat rata-rata (Yuwanta 2010).

\section{Analisa Data}

\section{Pengaruh Perlakuan Terhadap} Berat Telur

Data hasil pengamatan dan perhitungan rata-rata berat telur dari masing-masing perlakuan yang diberikan selama penelitian tercantum pada Tabel 1.

Data yang diperoleh pada penelitian ini ditabulasi dan dianalisa

Tabel 1. Rataan Berat Telur (g/butir)

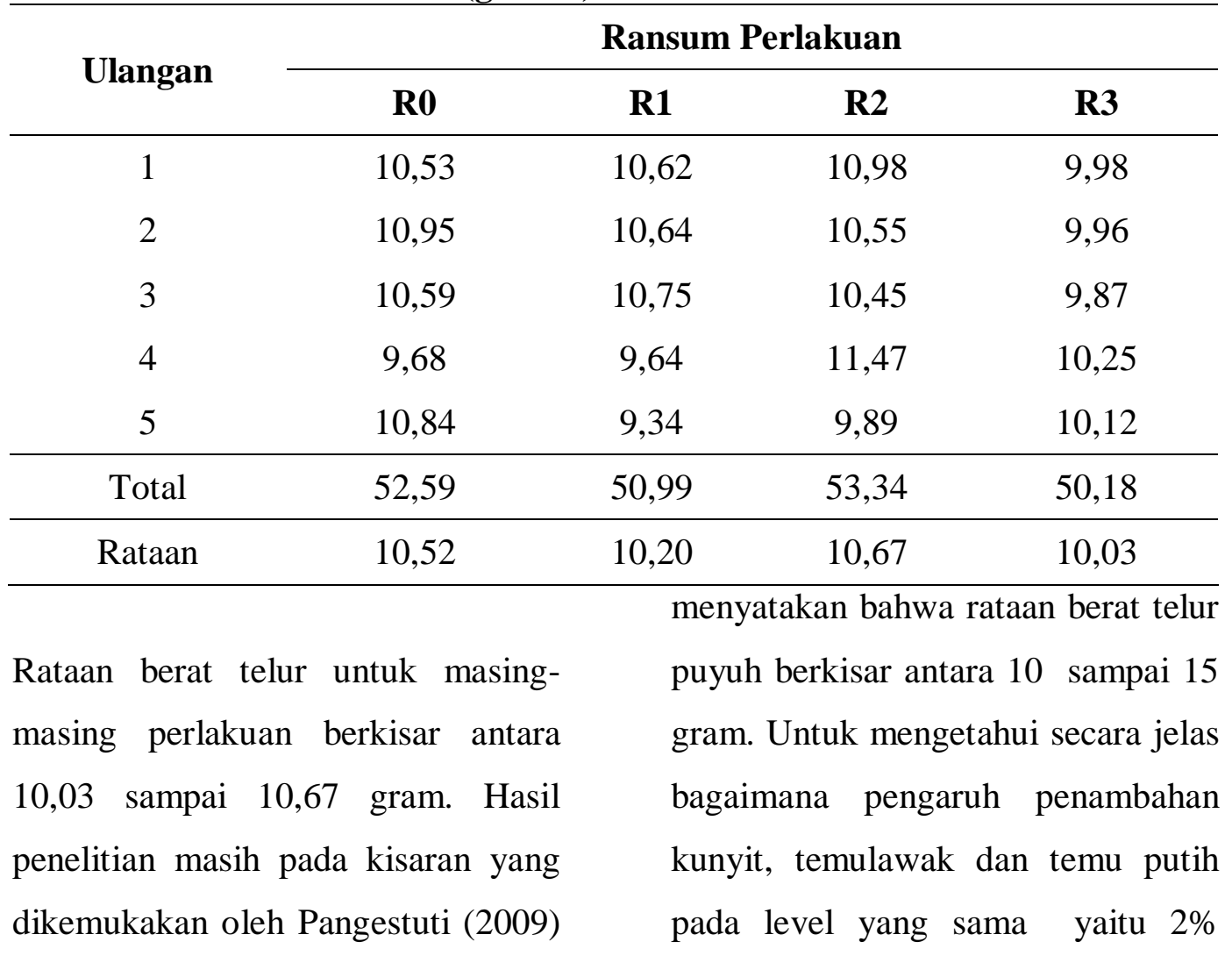


dibandingkan dengan ransum kontrol (komersil) terhadap berat telur burung puyuh maka dilakukan analisis statistik yang hasilnya tercantum pada Lampiran 1. Berdasarkan analisis sidik ragam pada lampiran tersebut terlihat bahwa pengaruh penambahan kunyit, temulawak, dan temu putih pada level yang sama yaitu $2 \%$

dibandingkan dengan ransum kontrol (komersil) tidak memberikan pengaruh yang nyata $(\mathrm{P}>0,05)$ terhadap berat telur burung puyuh. Artinya penambahan 2\% rimpang kunyit, temulawak, dan temu putih dalam ransum belum memberikan perbedaan pada berat telur.

Pengaruh perlakuan yang tidak berbeda nyata terhadap berat telur pada penelitian ini menggambarkan bahwa penambahan $2 \%$ rimpang kunyit, temulawak, dan temu putih dalam ransum burung puyuh, tidak menyebabkan penurunan kualitas dan kuantitas telur, dalam arti kandungan zat-zat makanan yang ditambahkan dalam ransum kontrol (komersil) seperti kandungan protein, lemak dan asamasam amino masih mencukupi kebutuhan burung puyuh dan tidak mempengaruhi keseimbangan zat-zat makanan dalam ransum, sehingga pertumbuhan dan produksi telur yang optimum masih dapat tercapai.

Kunyit dalam bentuk tepung dapat digunakan untuk mengoptimalkan kerja organ pencernaan karena kunyit yang termasuk tanaman famili zingiberaceae yang sering digunakan oleh masyarakat untuk meningkatkan nafsu makan dan mengobati kelainan organ tubuh khususnya pencernaan. Jika ditambahkan dalam pakan, kunyit diharapkan dapat meningkatkan kerja organ pencernaan, dan akhirnya berpengaruh terhadap kualitas karkas ayam pedaging. Fungsi kunyit dalam meningkatkan kerja organ pencernaan unggas adalah merangsang dinding kantong empedu mengeluarkan cairan empedu dan merangsang keluarnya getah pankreas yang mengandung enzim amilase, lipase, dan protease yang berguna untuk meningkatkan pencernaan bahan pakan seperti karbohidrat, lemak, dan protein. Disamping itu minyak atsiri yang dikandung kunyit dapat 
mempercepat pengosongan isi lambung (Riyadi, 2009).

Penambahan rimpang kunyit, temulawak dan temu putih dalam ransum akan meningkatkan proses pencernaan makanan dalam saluran pencernaan karena rimpang kunyit, temulawak dan temu putih mengandung kurkuminoid yang dapat merangsang dining kantong empedu untuk mengeluarkan cairan empedu dan minyak atsiri yang berfungsi mengatur keluarnya asam lambung agar tidak berlebihan sehingga membantu kerja usus. Peningkatan proses pencernaan akan mnjadikan substrat hasil metabolisme yang diserap menjadi semakin banyak. Semakin banyak produk metabolisme yang diserap akan mempengaruhi nilai status darah dan secara langsung akan meningkatkan status gizi pakan dalam proses metabolisme yang dihasilkan, sehingga dapat menunjang proses-proses fisiologis dalam tubuh (Erniasih dan Saraswati, 2006).

\section{Pengaruh Perlakuan Terhadap Warna Kuning Telur}

Data hasil pengamatan dan perhitungan rata-rata warna kuning telur dari masing-masing perlakuan yang diberikan selama penelitian tercantum pada Tabel 2.

Tabel 2. Rataan Warna Kuning Telur

\begin{tabular}{ccccc}
\hline \multirow{2}{*}{ Ulangan } & \multicolumn{5}{c}{ Ransum Perlakuan } \\
\cline { 2 - 5 } & $\mathbf{R 0}$ & $\mathbf{R 1}$ & $\mathbf{R 2}$ & $\mathbf{R 3}$ \\
\hline 1 & 8,00 & 8,00 & 6,00 & 7,00 \\
2 & 7,00 & 8,00 & 8,00 & 7,00 \\
3 & 8,00 & 7,00 & 7,00 & 6,00 \\
4 & 6,00 & 8,00 & 6,00 & 7,00 \\
5 & 7,00 & 8,00 & 6,00 & 7,00 \\
\hline Total & 36,00 & 39,00 & 33,00 & 34,00 \\
\hline Rataan & 7,20 & 7,80 & 6,60 & 6,80 \\
\hline \multirow{2}{*}{ Rataan } & \multirow{2}{*}{ warna } & kuning & telur & \multicolumn{2}{c}{ sampai 7,80. Skor warna kuning telur } \\
hasil penelitian untuk masing-masing & \multicolumn{2}{c}{ hasil penelitian apabila dibandingkan }
\end{tabular}


dengan penelitian Rachmat (2008) tidak jauh berbeda yaitu berada pada skor ke-8. Keadaan ini menandakan penambahan $2 \%$ rimpang kunyit, temulawak, dan temu putih dalam ransum burung puyuh, tidak menunjukkan efek negatif terhadap pembentukan kuning telur melainkan memberikan warna (pigmen) kuning yang baik pada kuning telur (yolk) sehingga menarik perhatian konsumen pada saat mengkonsumsi telur. Hal tersebut terlihat dengan jelas terjadi peningkatan warna kuning telur burung puyuh pada perlakuan rimpang kunyit yang mengandung zat aktif kurkuminoid sebagai pemberi warna (pigmen) kuning.

Berdasarkan analisis sidik ragam terlihat bahwa pengaruh penambahan kunyit, temulawak, dan temu putih pada level yang sama yaitu $2 \%$ dibandingkan dengan ransum kontrol (komersil) tidak memberikan pengaruh yang nyata $(\mathrm{P}>0,05)$ terhadap warna kuning telur burung puyuh. Artinya penambahan $2 \%$ rimpang kunyit, temulawak, dan temu putih dalam ransum tidak memberikan perbedaan pada warna kuning telur, karena masih dalam kisaran yang sama dengan warna kuning telur pada burung puyuh yang diberikan ransum kontrol (komersil) tanpa rimpang kunyit, temulawak, dan temu putih.

Pengaruh perlakuan yang tidak berbeda nyata terhadap warna kuning telur pada penelitian ini menggambarkan penambahan $2 \%$ rimpang kunyit, temulawak, dan temu putih dalam ransum burung puyuh, tidak menyebabkan penurunan kualitas telur, dalam arti kandungan zat-zat makanan yang ditambahkan dalam ransum kontrol (komersil) terutama kandungan zat warna kuning yang disebut kurkuminoid masih mencukupi kebutuhan burung puyuh dan tidak mempengaruhi keseimbangan zat-zat makanan dalam ransum, sehingga warna kuning telur yang optimum masih dapat tercapai. Semakin tinggi kandungan rimpang kunyit, temulawak, dan temu putih dalam ransum semakin besar karoten yang akan terdeposisi dalam kuning telur sehingga akan mempengaruhi warna kuning telur tersebut. Sejalan dengan pendapat Chung (2002), bahwa tipe dan jumlah pigmen karotenoid yang dikonsumsi oleh unggas petelur 
merupakan faktor utama dalam pigmentasi kuning telur.

\section{Pengaruh Perlakuan Terhadap Tebal Kerabang}

Data hasil pengamatan dan perhitungan rata-rata tebal kerabang dari masing-masing perlakuan yang diberikan selama penelitian tercantum pada Tabel 5. Rataan tebal kerabang telur untuk masing-masing perlakuan berkisar antara 0,150 sampai $0,154 \mathrm{~mm}$. Hasil penelitian masih pada kisaran yang dikemukakan oleh Tiwari dan Panda (1978) menyatakan ketebalan kerabang berkisar antara 0.13 sampai dengan $0.21 \mathrm{~mm}$. Keadaan ini menandakan penambahan $2 \%$ rimpang kunyit, temulawak, dan temu putih dalam ransum burung puyuh, tidak menunjukkan efek negatif terhadap pembentukan tebal kerabang melainkan dapat memperbaiki kerabang telur karena kerabang merupakan kulit telur yang berfungsi melindungi isi telur dari masuknya bakteri penyebab kerusakan pada isi telur yang dapat menurunkan kualitas telur.

Berdasarkan analisis sidik ragam pada lampiran tersebut terlihat bahwa pengaruh penambahan kunyit, temulawak dan temu putih pada level yang sama yaitu $2 \%$ dibandingkan dengan ransum kontrol (komersil) tidak memberikan pengaruh yang nyata $(\mathrm{P}>0,05)$ terhadap tebal kerabang telur burung puyuh. Artinya penambahan 2\% rimpang kunyit, temulawak, dan temu putih dalam ransum tidak memberikan perbedaan pada tebal kerabang telur, karena masih dalam kisaran yang sama dengan berat telur pada burung puyuh yang diberikan ransum kontrol (komersil) tanpa rimpang kunyit, temulawak, temu putih. Pengaruh perlakuan yang tidak berbeda nyata terhadap tebal kerabang telur pada penelitian ini menggambarkan penambahan $2 \%$ rimpang kunyit, temulawak, dan temu putih dalam ransum burung puyuh, tidak memberikan dampak yang nyata terhadap perubahan tebal kerabang telur. Hal tersebut disebabkan oleh kandungan zat-zat makanan yang ditambahkan dalam ransum kontrol (komersil) terutama kandungan kalsium masih mencukupi kebutuhan burung puyuh dan tidak mempengaruhi keseimbangan zat-zat makanan dalam ransum, sehingga tebal 
kerabang telur yang optimum masih

dapat tercapai.

Tabel 3. Rataan Tebal Kerabang Telur (mm)

\begin{tabular}{ccccc}
\hline \multirow{2}{*}{ Ulangan } & \multicolumn{4}{c}{ Ransum Perlakuan } \\
\cline { 2 - 5 } & $\mathbf{R 0}$ & $\mathbf{R 1}$ & $\mathbf{R 2}$ & $\mathbf{R 3}$ \\
\hline 1 & 0,17 & 0,15 & 0,16 & 0,15 \\
2 & 0,15 & 0,16 & 0,15 & 0,16 \\
3 & 0,15 & 0,15 & 0,16 & 0,15 \\
4 & 0,14 & 0,13 & 0,15 & 0,14 \\
5 & 0,16 & 0,16 & 0,14 & 0,15 \\
\hline Total & 0,77 & 0,75 & 0,76 & 0,75 \\
\hline Rataan & 0,154 & 0,150 & 0,152 & 0,150 \\
\hline
\end{tabular}

Hal ini dipengaruhi oleh kandungan kalsium yang terkandung di dalam bahan pakan maupun kunyit, temulawak dan temu putih. Oleh karena itu burung puyuh yang mendapat makanan dengan kandungan kalsium $(\mathrm{Ca})$ yang cukup banyak akan menghasilkan telur dengan kulit yang lebih tebal (Suprijatna dan Furi, 2008).

\section{KESIMPULAN}

Berdasarkan hasil analisa data dan pembahasan untuk semua variabel pada penelitian ini, maka dapat disimpulkan bahwa penambahan $2 \%$ rimpang kunyit, temulawak, dan temu putih belum dapat meningkatkan berat telur, warna kuning telur, dan tebal kerabang telur bila ditambahkan pada ransum komersil.

\section{DAFTAR PUSTAKA}

Anggraini, P. (2012). Pemanfaatan Temulawak (Curcuma xanthorrhiza Roxb) Dan Kunyit (Curcuma domestica Val) Sebagai Feed Additive Herbal Untuk Ayam Broiler. Jurusan Peternakan, Fakultas Pertanian,

Universitas Bengkulu.

Atmajaya et al, 2014. Pengaruh Penambahan Kunyit

(Curcuma Domestica Val)

Dan Temulawak

(Curcumaxanthorrhiza Roxb)

Dalam Air Minum Terhadap 
Persentase Dan Kualitas

Organoleptik Karkas Ayam

Broiler,

Universitas

Brawijaya.

Chung Tk. 2002. Yellow and red careotenoids for egg yolk pigmentation. $10^{\text {th }}$

Annual ASA Southeast Asian Feed Technology and Nutrition Workshop. Merlin Beach Resort, Phuket, Thailand.

Erniasih, I. dan Saraswati, T. R. 2006. Penambahan Limbah Padat Kunyit (Curcuma Domestica) pada Ransum Ayam dan Pengaruhnya terhadap Status Darah dan Hepar Ayam (Gallus sp). Buletin Anatomi dan Fisiologi Vol. XIV, No.2, Oktober 2006.

Heyne, K., 1987, Tumbuhan Berguna Indonesia, diterjemahkan oleh Badan Litbang Kehutanan Jakarta, Jilid II,Edisi I, Badan Litbang Kehutanan Jakarta.

Muharlien, 2010. Meningkatkan Kualitas Telur Melalui Penambahan Teh Hijau Dalam Pakan Ayam Petelur. http://jitek.ub.ac.id/index.php/j itek/article/download/154/147. Diakses tanggal 25 Januari 2013

Pangestuti, 2009. Analisis Kelayakan Usaha Peternakan Puyuh Pada Peternakan Puyuh Bintang Tiga Desa Situ Ilir, Kecamatan Cibungbulang, Kabupaten Bogor. Skripsi. Departemen Agribisnis akultas Ekonomi dan Manajemen Institut Pertanian Bogor. Bogor.

Rachmat dan Kusnadi. 2008. Pengaruh Penambahan Tepung Kunyit (Curcumadomestica Val.) dalam Ransum Yang Diberi MinyakJelantah terhadap Performan Ayam Broiler(The Effect of Curcuma domestica In Ration ThatContaining Residue Coconut Oil on BroilerPerformance)

Riyadi, Slamet, 2009. Kunyit dan Jahe Baik untuk Ayam Broiler. http//slametriyadi03.blogspot.com/2009/ 04/kunyit-dan-jah-baikuntuk-broiler.html. 
Steel R.G.D., and J.H. Torrie. 1994.

Prinsip dan Prosedur

Statistika, Suatu

Pendekatan Biometrik. Alih

bahasa B. Sumanti. PT

Gramedia Pustaka Utama.

Jakarta.

Suprijatna, E. S. \& N. R. Furi. 2008.

Penampilan produksi dan kualitas

telur pada puyuh (Coturnix-

coturnix japonica) yang

memperoleh ransum protein

rendah disuplementasi enzim

komersial. J. Indonesia. Trop.

Anim. Agric. 33 (1): 68

Tiwari K.S, and B. Panda. 1978.

Production and quality

characteristic of quail

eggs. Indian J of Poultry Sci

13 :n 27-32.

Yuwanta, T. 2010. Telur dan

Kualitas Telur. Gajah Mada

University Press,

Yogyakarta.

Zainuddin, D. 2010. "Tanaman Obat

Meningkatkan Efisiensi Pakan Dan

Kesehatan Ternak Unggas".

Hasil Penelitian Desmayati

Zainuddin Balai Penelitian

Ternak Jl. Veteran - III PO

Box 221, Bogor 16002. 
